DOI: $10.4067 / \mathrm{S} 0718-162020150002000010$

\title{
RESEARCH PAPER \\ Enhanced secretion of biocontrol enzymes by Trichoderma harzianum mutant strains in the presence of Rhizoctonia solani cell walls
}

\author{
Rubén Polanco ${ }^{1}$, Constanza Pino 1 , Ximena Besoain ${ }^{2}$, Jaime Montealegre ${ }^{3}$, and Luz \\ M. Pérez ${ }^{4}$ \\ ${ }^{1}$ Laboratorio de Bioquímica, Departamento de Ciencias Biológicas, Facultad de Ciencias Biológicas, \\ Universidad Andrés Bello, República 217, Santiago, Chile. \\ ${ }^{2}$ Facultad de Agronomía, Pontificia Universidad Católica de Valparaíso, Casilla 4059, Valparaíso, Chile. \\ ${ }^{3}$ Departamento de Sanidad Vegetal. Facultad de Ciencias Agronómicas, Universidad de Chile, Casilla 1004, \\ Santiago, Chile. \\ ${ }^{4}$ Asesorías e Inversiones Biostrategy Ltda., Hernando de Aguirre 1372, Santiago, Chile.
}

\begin{abstract}
R. Polanco, C. Pino, X. Besoain, J. Montealegre and L. M. Pérez. 2015. Enhanced secretion of biocontrol enzymes by Trichoderma harzianum mutant strains in the presence of Rhizoctonia solani cell walls. Cien. Inv. Agr. 42(2):243-250. The secretion of enzymes involved in biocontrol from the wild T. harzianum strains Th11 and Th12 and the mutants Th11A80.1, Th11C40.1 and Th12A10.1 was studied after their cultivation in the presence of $R$. solani cell walls as the sole carbon source. The results showed that endoprotease activity in the supernatants from Th11A80.1 and Th11C40.1 increased 2.77 and 4.79-fold, respectively, and the $\beta$-1,3-glucanase and $\beta$-1,4-chitinase activity from Th12A10.1 increased 1.86 and 1.54-fold, respectively, compared with the corresponding parental strains. The role of the three enzymes in the biocontrol of $R$. solani is discussed.
\end{abstract}

Key words: $\beta$-1,3-glucanases, endoproteases, $\beta$-1,4-chitinases.

\section{Introduction}

Several plant diseases are normally controlled by means of selected fungicides that contaminate the environment, destroy the soil microbiota, and the fungicides must be applied frequently because of the fast decrease in their activity. Due to this situation, several disease management practices have been proposed, including the use

Received September 9, 2014. Accepted June 22, 2015. Corresponding author: jmonteal@uchile.cl of Trichoderma spp. that have been proven useful in the control of phytopathogens affecting different crops (Benítez et al., 2004). Wild T. harzianum strains have already demonstrated their positive biocontrol effect on the tomato pathogens Pyrenochaeta lycopersici (Pérez et al., 2002; Besoain et al., 2003) and Rhizoctonia solani (Montealegre et al., 2005). However, the biocontrol effect could be improved by obtaining mutants with an improved biocontrol capacity. Some mutants obtained after the UV irradiation and protoplast fusion of $T$. harzianum (Besoain 
et al., 2007) have shown an improved biocontrol effect on P. lycopersici (Sánchez-Téllez et al., 2013). Additionally, some of these mutants have shown a biocontrol effect on $R$. solani (Montealegre et $a l ., 2010)$. However, it is unknown whether these T. harzianum mutants have changed their ability to secrete extracellular enzymes involved in biocontrol such as $\beta$-1,3-glucanases, endoproteases and $\beta-1,4$-chitinases. The present work provides information on the secretion of these enzymes by selected wild and mutant T. harzianum strains and how their secretion is involved in the biocontrol effect on phytopathogens.

\section{Materials and methods}

\section{Microorganisms}

R. solani 618 (AG 4); T. harzianum Th11 and Th12 (wild strains); and ThA11.80.1, Th11C.40.1, and Th12A10.1 (mutant strains) were obtained from the laboratory collection (Laboratorio de Fitopatología y Control Biológico de Enfermedades).

\section{Production of extracellular enzymes}

The production of extracellular enzymes was induced in submerged cultures of each of the wild (Th11 and Th12) and mutant (ThA11.80.1, Th11C.40.1 and Th12A10.1) T. harzianum strains. The cultures were carried out in triplicate in conical flasks containing $200 \mathrm{~mL}$ of Mandels Salt Solution (Mandels et al., 1974) with the addition of $5 \mathrm{~g} \mathrm{~L}^{-1}$ of $R$. solani cell walls as the sole carbon source (Pérez et al., 2002). Briefly, cell walls were obtained from $50 \mathrm{~mL}$ of a five-day culture of $R$. solani in Mandels Salt Solution at $27^{\circ} \mathrm{C}$ and $120 \mathrm{rpm}$ (orbital shaker). The suspension was filtered to eliminate conidia, and the non-filtered remainder was suspended in distilled autoclaved water, thoroughly stirred and centrifuged at $30,000 \times g$ at $4{ }^{\circ} \mathrm{C}$. The pellet suspension, stirring and centrifugation was repeated until no residual glucose, protein or amino acids could be detected in the supernatant, as performed in Sivan and Chet (1989). The final pellet was freeze-dried and kept at $-20{ }^{\circ} \mathrm{C}$ until use. Each flask was inoculated with $5 \times 10^{6}$ conidia of $T$. harzianum strains. The cultures were incubated in an orbital shaker incubator at $28^{\circ} \mathrm{C}$ and $200 \mathrm{rpm}$. After seven days, the cultures were centrifuged at $12,000 \times g$ and $4{ }^{\circ} \mathrm{C}$. The supernatants were assayed for protein quantification and enzymatic activity, and the mycelia were used for weight quantification. These parameters were used to compare the mutants with their corresponding wild parental strains.

\section{Protein quantification}

The proteins from the supernatants from each strain were quantified using the Bio-Rad Protein Assay following the instructions of the manufacturer. They are expressed as concentration $\left(\mathrm{mg} \mathrm{mL}^{-1}\right)$ and total protein (mg or $\mu \mathrm{g}$ ).

\section{Enzymatic assays}

$\beta$-1,3-glucanase was assayed using $0.1 \%$ AZCLPachyman in $100 \mathrm{mM}$ sodium acetate with a $\mathrm{pH}$ of 6.0 and $10 \mu \mathrm{g}$ of protein from the supernatants from each strain following the instructions of the manufacturer (Megazyme, Ireland). The enzyme unit was defined as the amount of enzyme necessary to produce $0.1 \Delta$ Absorbance at $590 \mathrm{~nm}$ in a one-hour assay at $38^{\circ} \mathrm{C}$. The assays were run in quadruplicate and repeated three times.

Endoprotease was assayed using 0.1\% AZCLCasein in $100 \mathrm{mM}$ sodium phosphate with a $\mathrm{pH}$ of 7.0 and $10 \mu \mathrm{g}$ of proteins from the supernatants from each strain following the instructions of the manufacturer (Megazyme, Ireland). The enzyme unit was defined as the amount of enzyme necessary to produce a $0.1 \Delta \mathrm{Abs}$ at $590 \mathrm{~nm}$ in a one-hour assay at $38^{\circ} \mathrm{C}$. The assays were run in quadruplicate and repeated three times. 
$\beta-1,4$-chitinase was assayed in agarose gels as previously described (Pérez et al., 2002) using the supernatants from each strain as the enzyme source and a known activity of commercial $\beta$-1,4-endochitinase from Serratia marcescens (Sigma) as the internal standard. The Gel-Pro Analyzer Program (Install Shield Company) was used after developing the enzymatic activity as previously described (Pérez et al., 2002). The assays were run in quadruplicate and repeated three times. The enzyme unit was defined as the amount of enzyme necessary to release $1.0 \mathrm{mg}$ of $\mathrm{N}$-acetyl-D-glucosamine released from the chitin per hour at $\mathrm{pH} 6.0$ at $25^{\circ} \mathrm{C}$ in a 2-hour assay.

\section{Quantification of mycelial dry weight}

The mycelial from each strain were dried in an oven at $80^{\circ} \mathrm{C}$ for $5 \mathrm{~h}$ and weighed on an analytical balance.

\section{Analysis of data}

The data on the protein concentration and enzyme activity found in the supernatants, both for the parental and mutant $T$. harzianum strains, were analyzed by ANOVA followed by Tukey's test $(\mathrm{P} \leq 0.05)$ using the Stadistica6 Program (Statsop).

\section{Results and discussion}

\section{Mycelial dry weight of T. harzianum strains}

The ability of the T. harzianum strains Th11, Th11A80.1, Th11C40.1, Th12 and Th12A10.1 to grow using $R$. solani cell walls as the sole carbon source was reflected in the corresponding mycelial dry weight after the incubation period, as well as on the ratio of the Strain/Parent mycelial dry weight (Table 1). The mycelial dry weight of the mutants from Th11 was significantly lower than that of the corresponding parental strain, suggesting that the UV-A or UV-C radiation previously used for obtaining the mutants (Besoain et al., 2007) may have affected their ability to grow at the same speed as the wild strains in the presence of $R$. solani cell walls as the sole carbon source. These lower dry weights and Strain/Parent ratios less than one reflect the lower amount of growth of the mutants in relation to Th11 in the same growing conditions, suggesting that proteolysis could have been enhanced or that the secretory pathway could have been affected (Flores et al., 1997). On the other hand, the mycelial dry weight from Th12 and Th12A10.1 did not significantly differ, which indicates that the UV-A radiation used for obtaining Th12A10.1 (Besoain et al., 2007) did not alter its ability to grow in the presence of $R$. solani cell walls. The use of different mutation strategies have been reported to induce the secretion of hydrolytic enzymes in T. harzianum strains (Vásquez-Garcidueñas et al., 1998; Rey et al., 2001; Pérez et al., 2007), although data on the mycelial dry weight are not always reported.

Proteins and enzymatic activity in the supernatants of T. harzianum strains

The total protein in the supernatants of the culture medium of the different $T$. harzianum strains grown in the presence of $R$. solani cell walls, expressed in $\mathrm{mg}$ and also based on the mycelial dry weight, is shown in Table 1. The protein concentration in the supernatants and the ratio of the Strain/Parent protein concentration are also shown in Table 1. Only Th11C40.1 showed a significant increase in secreted protein concentration. This is in contrast with its significant decrease in mycelial dry weight when compared with its parental strain Th11, reflected in the c.a. four-fold increase in its efficiency to secrete proteins based on the mycelial dry weight in comparison with Th11. The increase in secreted proteins by the $T$. harzianum mutant Th11C40.1 as a consequence of UV-C radiation could be related to post-translational events such as those related to secretory pathways and/or membrane permeation, as previously described (Rey et al., 2001). This latter group used a similar 
Table 1. Mycelial dry weight and protein concentration in supernatants of different T. harzianum strains cultivated over seven days in the presence of $R$. solani cell walls as the sole carbon source.

\begin{tabular}{|c|c|c|c|c|c|c|c|}
\hline & Type of strain & $\begin{array}{l}\text { Mycelial } \\
\text { dry weight } \\
(\mathrm{mg})\end{array}$ & $\begin{array}{c}\text { Ratio dry } \\
\text { weight Strain/ } \\
\text { Parent }\end{array}$ & $\begin{array}{c}\text { Protein } \\
\text { concentration } \\
\text { in supernatants } \\
\left(\mathrm{mg} \mathrm{mL}^{-1}\right)\end{array}$ & $\begin{array}{l}\text { Ratio protein } \\
\text { concentration } \\
\text { Strain/Parent }\end{array}$ & $\begin{array}{l}\text { Total protein } \\
\text { in the } \\
\text { supernatant } \\
(\mathrm{mg})\end{array}$ & $\begin{array}{l}\text { Total protein } \\
\text { based on } \\
\text { mycelial dry } \\
\text { weight (mg } \\
\left.\mathrm{mg}^{-1}\right)\end{array}$ \\
\hline \multicolumn{8}{|l|}{ A. Series Th11 } \\
\hline \multicolumn{8}{|c|}{ T. harzianum strains (series Th11) } \\
\hline Th11 & Parent & $116.5 \mathrm{a}$ & 1.00 & $0.013 \mathrm{~b}$ & 1.00 & 2.6 & 0.022 \\
\hline Th11A80.1 & UV-A mutant & $84.5 \mathrm{~b}$ & 0.73 & $0.016 \mathrm{~b}$ & 1.23 & 3.2 & 0.037 \\
\hline Th11C40.1 & UV-C mutant & $66.5 \mathrm{~b}$ & 0.57 & $0.027 \mathrm{a}$ & 2.07 & 5.4 & 0.081 \\
\hline \multicolumn{8}{|l|}{ B. Series Th12 } \\
\hline \multicolumn{8}{|c|}{ T. harzianum strains (series Th12) } \\
\hline Th12 & Parent & $91.25 \mathrm{a}$ & 1.00 & $0.022 \mathrm{a}$ & 1.00 & 4.4 & 0.048 \\
\hline Th12A10.1 & UV-A mutant & $95.00 \mathrm{a}$ & 1.04 & $0.025 \mathrm{a}$ & 1.14 & 5.0 & 0.052 \\
\hline
\end{tabular}

Different letters in the columns indicate significant differences after analysis by ANOVA followed by the Tukey's test at $\mathrm{p}<0.05$ within the same series.

approach when comparing a mutant of $T$. harzianum CECT 2413 that secretes more extracellular proteins with the corresponding parental strain (Rey et al., 2001).

The $\beta$-1,3-glucanase, endoprotease and $\beta-1,4$ chitinase activity in the supernatants of the culture medium of the different $T$. harzianum strains grown in the presence of $R$. solani cell walls, expressed as Units $\mathrm{mL}^{-1}$, Units/mg proteins and Total Units, are shown in Table 2.

The T. harzianum mutant Th12A10.1 was the only strain that significantly increased its $\beta-1,3$ glucanase and $\beta$-1,4-chitinase activity as reflected in the ratios of total Strain/Parent activity (Table $2 \mathrm{~A}$ and $2 \mathrm{C}$ ). This mutant had previously shown an in vitro inhibitory effect on $R$. solani due to diffusible metabolites (Arias et al., 2006) and an in vivo $100 \%$ suppression of tomato plant mortality compared with the $20 \%$ suppression observed with Th12 (Montealegre et al., 2010). Thus, the increased secretion of $\beta-1,3$-glucanase and $\beta-1,4$-chitinase from this mutant could be related to the enhanced biocontrol effect on phytopathogens using cell walls containing both glucan and chitin (Bartnicki-García, 1968). However, this mutant did not show a significant increase in secreted proteins (Table 1); therefore, the increase in the secretion of these biocontrol enzymes could not be attributed to the changes in membrane permeation or in their secretory pathway (Rey et al., 2001), as has been suggested for the mutant PF1 of T. harzianum CECT 2413 where the secretion of proteins was enhanced three times the value of the wild type along with the increased activity of $\beta$-1,3-glucanase, $\beta$-1,6-glucanase and chitinase (Rey et al., 2001). In addition, the mutant PF1 of $T$. harzianum CECT 2413 produced $100 \%$ mortality in $R$. solani. Additionally, a simultaneous increase in $\beta$-1,4-chitinase and $\beta$-1,3-glucanase activity has been reported for the T. harzianum mutant Th650NG-7, which also shows an improved biocontrol activity against $R$. solani (Pérez et al., 2007) and a $100 \%$ suppression of tomato plant mortality caused by the same pathogen (Montealegre et al., 2010). Thus, it appears that in terms of the specific $R$. solani cell wall degradation, the simultaneous action of these two enzymes is required (Potgieter and Alexander, 1966; Rey et al., 2001) due to its chitin-glucan composition (Bartnicki-García, 1968). However, different pathogens have different cell wall compositions; therefore, the composition must be taken into account when analyzing and selecting biocontrol microorganisms and their secreted enzymes. 
Table 2. $\beta$-1,3-glucanase, endoprotease and $\beta$-1,4-chitinase activity in the supernatant from the T. harzianum strains grown in Mandels Salt Medium with the presence of $R$. solani cell walls as the sole carbon source.

\begin{tabular}{|c|c|c|c|c|c|}
\hline & Type of strain & $\begin{array}{c}\text { Enzymatic activity } \\
\left(\mathrm{U} \mathrm{mL}^{-1}\right)\end{array}$ & $\begin{array}{l}\text { Specific activity } \\
\left(\mathrm{U} \text { mpprot }^{-1)}\right.\end{array}$ & Total activity (U) & $\begin{array}{l}\text { Ratio Total activity } \\
\text { (Strain/Parent) }\end{array}$ \\
\hline & & T. harzianum strain & & & \\
\hline \multicolumn{6}{|c|}{ A. $\beta$-1,3-glucanase } \\
\hline Th 11 & Parent & $0.006 \mathrm{a}$ & $0.49 \mathrm{a}$ & $1.274 \mathrm{a}$ & 1.00 \\
\hline Th 11 A80.1 & UV-A mutant & $0.004 \mathrm{~b}$ & $0.27 \mathrm{~b}$ & $0.864 \mathrm{~b}$ & 0.68 \\
\hline Th 11 C40.1 & UV-B mutant & $0.003 \mathrm{~b}$ & $0.13 \mathrm{c}$ & $0.691 \mathrm{c}$ & 0.54 \\
\hline Th 12 & Parent & $0.003 \mathrm{~b}$ & $0.14 \mathrm{~b}$ & $0.607 \mathrm{~b}$ & 1.00 \\
\hline \multirow[t]{2}{*}{ Th 12 A10.1 } & UV-A mutant & $0.006 \mathrm{a}$ & $0.23 \mathrm{a}$ & $1.130 \mathrm{a}$ & 1.86 \\
\hline & & T. harzianum strain & & & \\
\hline \multicolumn{6}{|l|}{ B. Endoprotease } \\
\hline Th 11 & Parent & $0.004 \mathrm{c}$ & $0.34 \mathrm{~b}$ & $0.887 \mathrm{c}$ & 1.00 \\
\hline Th 11 A80.1 & UV-A mutant & $0.012 \mathrm{~b}$ & $0.77 \mathrm{a}$ & $2.454 \mathrm{~b}$ & 2.77 \\
\hline Th 11 C40.1 & UV-C mutant & $0.021 \mathrm{a}$ & $0.79 \mathrm{a}$ & $4.250 \mathrm{a}$ & 4.79 \\
\hline Th 12 & Parent & $0.019 \mathrm{a}$ & $0.85 \mathrm{a}$ & $3.727 \mathrm{a}$ & 1.00 \\
\hline \multirow[t]{2}{*}{ Th 12 A10.1 } & UV-A mutant & $0.021 \mathrm{a}$ & $0.84 \mathrm{a}$ & $4.195 \mathrm{a}$ & 1.13 \\
\hline & & T. harzianum strain & & & \\
\hline \multicolumn{6}{|c|}{ C. $\beta$-1,4-chitinase } \\
\hline Th 11 & Parent & $0.003 \mathrm{a}$ & $0.22 \mathrm{a}$ & $0.559 \mathrm{a}$ & 1.00 \\
\hline Th 11 A80.1 & UV-A mutant & $0.003 \mathrm{a}$ & $0.20 \mathrm{a}$ & $0.643 \mathrm{a}$ & 1.15 \\
\hline Th 11 C40.1 & UV-B mutant & $0.003 \mathrm{a}$ & $0.10 \mathrm{~b}$ & $0.556 \mathrm{a}$ & 0.99 \\
\hline Th 12 & Parent & $0.003 \mathrm{~b}$ & $0.16 \mathrm{~b}$ & $0.695 \mathrm{~b}$ & 1.00 \\
\hline Th 12 A10.1 & UV-A mutant & $0.005 \mathrm{a}$ & $0.21 \mathrm{a}$ & $1.070 \mathrm{a}$ & 1.54 \\
\hline
\end{tabular}

Different letters in the columns indicate significant differences after analysis by ANOVA followed by the Tukey's test at $\mathrm{p}<0.05$ within the same series.

The T. harzianum mutants Th11A 80.1 and Th11C40.1 increased the secretion of endoprotease activity (Table 2B), maintained the secretion of $\beta$-1,4-chitinase (Table 2C) and decreased that of $\beta$-1,3-glucanase (Table 2A) when compared with the parental strain Th11. The increased secretion of endoproteases induced by the presence of the $R$. solani cell walls in these two mutants could explain their lower mycelial dry weight (Table 1). These two mutants have shown (Arias et al., 2006) the ability to secrete diffusible metabolites, which inhibited the in vitro growth of $R$. solani by $100 \%$ and $94.4 \%$, respectively. They also suppress tomato plant mortality (Montealegre et al., 2010). The ability of T. harzianum to produce extracellular proteases has been known for a long time, and these enzymes have been involved in the biocontrol of phytopathogens (Kredics et al., 2005). For example, a T. harzianum (IMI 206040) strain that over-expressed the proteinase-encoding gene prb1 (Flores et al., 1997) showed an improved biocontrol activity of $R$. solani. This prb1 gene codifies for a basic proteinase (Prb1) in $T$. harzianum, which is induced by autoclaved $R$. solani mycelia, fungal cell wall preparations, or chitin (Geremia et al., 1993). Additionally, the UV protease-overproducing T. harzianum mutants (Szekeres et al., 2004) and S. cerevisiae expressing a subtilisin-like protease from T. harzianum (Yan and Qian, 2009) have shown increased control of $R$. solani. The decline or deactivation of plant pathogen enzymes and the increase in susceptibility 
of the pathogen cell wall to hydrolytic enzymes secreted by T. harzianum are within the possible role of proteases in biocontrol by Trichoderma strains (Kredics et al., 2005). Thus, the increase in secreted endoproteases by the Th11-derived mutant strains Th11A80.1 and Th11C40.1 could account for the improved biocontrol activity based on the host lysis by attacking lipids and proteins, which are part of the cell wall skeleton of the phytopathogens, and/or by degrading enzymes used by the phytopathogens to penetrate the host plant.

Finally, the decrease in $\beta-1,3$-glucanase and the maintenance of $\beta-1,4$-chitinase activity by the Th11-derived mutants (Table 2A and 2C) suggest that the mutations produced by UV-A or UV-C radiation might have affected only the secretion of glucanases.

The enhanced activity of $\beta$-1,3-glucanase and $\beta$-1,4-chitinase in the T. harzianum mutant Th12A10.1 and of endoprotease in the T. harzianum mutants Th11A80.1 and Th11C40.1 in response to the presence of $R$. solani cell walls supports not only the already-tested improved biocontrol effect on this pathogen (Arias et al., 2006; Montealegre et al., 2010) but also the joint action of $\beta$-1,3-glucanase and $\beta$-1,4-chitinase and the independent effect of proteolytic activity for pathogen cell wall degradation. The characterization of each wild or mutant T. harzianum strain, in terms of the secreted enzyme activity, must be considered for the selection of biocontrol strains as along with the cell wall composition of the pathogen to be controlled. Mutations could enhance the secretion of biocontrol enzymes, and the resulting mutants could behave better, equal or worse than the corresponding parental strains. Thus, the selection of biocontrol strains will rely on the pathogen to be controlled and the enzyme systems that could provide the biocontrol agent for pathogen cell wall degradation and/or for the degradation/inactivation of the mechanisms used by the pathogen to cause disease.

\section{Acknowledgements}

This work was partially funded by FONDECYT (Fondo Nacional de Desarrollo Científico y Tecnológico, Chile) project 104053124 (Uso de bioantagonistas mejorados para el control de Pyrenochaeta lycopersici, Phytophthora parasitica y Rhizoctonia solani en el cultivo del tomate).

\section{Resumen}

R. Polanco, C. Pino, X. Besoain, J. Montealegre and L. M. Pérez. 2015. Aumento de secreción de enzimas de biocontrol en cepas mutantes de Trichoderma harzianum en presencia de paredes de Rhizoctonia solani. Cien. Inv. Agr. 42(2): 243-250. La secreción de enzimas involucradas en biocontrol por las cepas silvestres de T. harzianum Th11 y Th12, y de sus mutantes Th11A80.1, Th11C40.1 y Th12A10.1, se analizó luego de cultivarlas en medio líquido usando paredes celulares de $R$. solani como única fuente de carbono. Los resultados mostraron que Th11A80.1 y Th11C40.1 aumentaron la secreción de endoproteasas 2,77 y 4,79 veces, respectivamente; Th12A10.1 aumentó 1,86 veces la secreción de $\beta$-1,3-glucanasa y 1,54 veces la de $\beta$-1,4-quitinasa al compararlas con las cepas parentales. Se discute el rol de estas tres enzimas para el biocontrol de fitopatógenos.

Palabras clave: $\beta$-1,3-glucanasa, $\beta$-1,4-quitinasa, endoproteasas. 


\section{References}

Arias, M., R. Herrera, X. Besoain, L.M. Pérez, and J. Montealegre. 2006. Evaluación in vitro de mutantes de cepas de Trichoderma para el control de Rhizoctonia solani y Phytophthora nicotianae en tomate. Boletín Micológico 21: 71-75.

Bartnicki-García, S. 1968. Cell wall chemistry, morphogenesis, and taxonomy of fungi. Annual Review of Microbiology 22: 87-108.

Benítez, T., A. M., Rincón, M. Limón, and A. C. Codón. 2004. Biocontrol mechanisms of Trichoderma strains. International Microbiology 7: 249-260.

Besoain, X., L. M. Pérez, A. Araya, Ll. Lefever, M. Sanguinetti and J. Montealegre. 2007. New strains obtained after UV treatment and protoplast fusion of native Trichoderma harzianum: their biocontrol activity on Pyrenochaeta lycopersici. Electron. J. Biotechnol. [online]. 15 October 2007, vol. 10, no. 4 [cited date]. Available at http://www.ejbiotechnology.info/content/ vol10/issue4/full/16

Besoain, X., G. Pardo, C. Raggi, M. Opazo, S. Araya, L. M. Pérez and J. Montealegre. 2003. Características de cepas chilenas de Pyrenochaeta lycopersici y perspectivas de control biológico. Boletín Micológico 18: 57-65.

Flores, A., I. Chet and A. Herrera-Estrella. 1997. Improved biocontrol activity of Trichoderma harzianum by over-expression of the proteinase-encoding gene prb1. Current Genetics 31: 30-37.

Geremia, R. H., G. H. Goldman, D. Jacobs, W. Ardrtes, S. B. Vila, M. Van Montagu and A. Herrera-Estrella. 1993. Molecular characterization of the proteinase-encoding gene, prb1, related to mycoparasitism by Trichoderma harzianum. Molecular Microbiology 8: 603-613.

Kredics, L., Z. Antal, A. Szekeres, L. Hatvani, L. Manczinger, C. S. Vágvölgyi and E. Nagy. 2005. Extracellular proteases of Trichoderma species. Acta Microbiologica et Immunologica Hungarica 52: 169-184.

Mandels, M., I. Hontz and J. Nystrom. 1974. Enzymatic hydrolysis of waste cellulose. Biotecnology and Bioengineering 16:1471-1493.
Montealegre J., L. Valderrama, S. Sánchez, R. Herrera, X. Besoain and L. M. Pérez. 2010. Biological control of Rhizoctonia solani in tomatoes with Trichoderma harzianum mutants. Electron. J. Biotechnol. [online] 13(2):1-2.

Montealegre, J., R. Herrera, J. C. Velásquez, P. Silva, X. Besoain and L. M. Pérez. 2005. Biocontrol of root and crown rot in tomatoes under greenhouse conditions using Trichoderma harzianum and Paenibacillus lentimorbus. Additional effect of solarization. Electron. J. Biotechnol. 8:249-257. Available at http:/www.ejbiotechnology.info/ content/vol13/issue 2/full/6

Pérez, L. M., X. Besoain, R. Reyes, G. Pardo and J. Montealegre. 2002. The expression of extracellular fungal cell wall hydrolytic enzymes in different Trichoderma harzianum isolates correlates with their ability to control Pyrenochaeta lycopersici. Biological Research 35: 401-410.

Pérez, L. M., R. Polanco, J. C. Ríos, J. Montealegre, L. Valderrama, R. Herrera and X. Besoain. 2007. The increase in endochitinases and $\beta-1,3-$ glucanases in the mutant Th650-NG7 of the Trichoderma harzianum Th650, improves the biocontrol activity on Rhizoctonia solani infecting tomato. IOBC/wprs Bulletin 30: 135-138.

Potgieter, H. J. and M. Alexander. 1966. Susceptibility and resistance of several fungi to microbial lysis. Journal of Bacteriology 91: 1526-1532.

Rey, M., J. Delgado-Jarana and T. Benítez. 2001. Improved antifungal activity of a mutant of Trichoderma harzianum CECT 2413 which produces more extracelular proteins. Applied Microbiology and Biotechnology 55: 604-608.

Sánchez-Téllez S., R. Herrera-Cid, X. Besoain-Canales, L. M. Pérez-Roepke and J. MontealegreAndrade. 2013. In vitro and in vivo inhibitory effect of solid and liquid Trichoderma harzianum formulations on Pyrenochaeta lycopersici. Interciencia 38: 425-429.

Sivan, A., and I. Chet. 1989. Degradation of Fungal Cell Walls by Lytic Enzymes of Trichoderma harzianum. Journal of General Microbiology 135: 675-682.

Szekeres, A., L. Kredics, Z. Antal, F. Kevei and L. Manczinger. 2004. Isolation and characterization 
of protease overproducing mutants of Trichoderma harzianum. FEMS Microbiology Letters 233: 215-222.

Vásquez-Garcidueñas, S., C. A. Leal-Morales and A. Herrera-Estrella. 1998. Analysis of the $\beta$-1,3glucanolytic system of the biocontrol agent
Trichoderma harzianum. Applied and Environmental Microbiology 64: 1442-1446.

Yan, L. and Y. Qian. 2009. Cloning and heterologous expression of SS10, a subtilisin-like protease displaying antifungal activity from Trichoderma harzianum. FEMS Microbiology Letters 290: 54-61. 